MOVERS

\section{Ed Holmes, executive deputy chairman, Biomedical Research Council, Singapore; and Judith Swain, executive director, Singapore Institute for Clinical Sciences.}
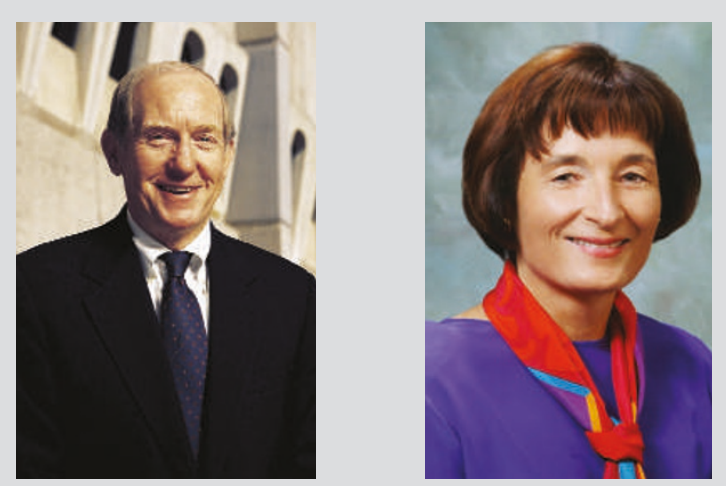

When physician-scientists Judith Swain and Ed Holmes take up their posts in Singapore later this year, they will join a star-studded community at one of the world's most rapidly developing biomedical research centres. The appointment of the married couple aroused a flurry of press, as they are the latest of many Western scientists who have headed for the impressive facilities of the tiny city state. During the past few years, Singapore's government has poured US $\$ 290$ million into its 'Biopolis'. Private investment has supplied another $\$ 500$ million.

Swain is a molecular cardiologist, known for work on the role of growth factors in regulating the angiogenic response - the body's ability to build and repair blood vessels - and its involvement in heart-muscle cell differentiation. A keen pilot, whose favourite challenge is landing on aircraft carriers, Swain has held advisory roles with both the US Department of Defense and NASA, which led to an interest in human performance in extreme environments.

A chemistry major, Swain attended medical school at the University of California, San Diego, where she studied cardiology. An internship at Duke University in Durham, North Carolina, extended to a 17-year stay. There, she met, married and co-authored papers with Holmes. Holmes, now a leading figure in translational research, has focused on the molecular basis of disease since his appointment as a Howard Hughes medical investigator at Duke in 1974.

Both have had links with Singapore for many years, and they play down 'brain drain' speculation. Only about 50 of the top people at Biopolis were poached from the United States or Europe. "A little concern is good, to get the United States to wake up and not be complacent," says Swain, noting that their move was prompted in part by federal hostility towards embryonic stem-cell research.

As a member of the governing body of California's stem-cell research institute, Holmes hopes opponents will soon run out of legal objections. Philip Yeo, Singapore's indefatigable recruiter, makes a point of promising academic freedom, along with 5-year contracts that allow people to spend their time on science rather than seeking funds.

Swain and Holmes will continue to work at San Diego, spending about half the year in each country and building research bridges between the two. Swain encourages fellow scientists to branch out globally. "Colleagues in other countries have done this for a long time, but Americans tend to be more insular," she says.

Janet Wright

\section{MENTORS \& PROTÉGÉS}

\section{The right advice}

Last autumn, I won a Presidential Award for Excellence in Science, Mathematics and Engineering Mentoring sponsored by the US National Science Foundation (NSF). I was humbled and surprised, as I've never viewed mentoring as an activity separate from my work.

I was fortunate to have several good mentors when I was a student. My undergraduate and dissertation supervisors encouraged me both to follow my scientific curiosity and to focus on my intellectual strengths, even when the two did not match up perfectly. They tolerated my insecurities and helped me to stay on track, mindful of funding and deadlines. Perhaps most importantly, I saw how they enjoyed their families and maintained some balance in their lives. They encouraged me to set my own hours and priorities, holding me accountable for my research without micromanaging the process. They taught me that the adviser's job is to help the student professionally - a student's publications should not be a means of bolstering the adviser's reputation.

I typically mentor students in classes, research internships or graduate programmes. One-to-one interaction is crucial for some, who lack confidence or focus. Many of my students are women, and we often discuss the climate in academia, the difficulties of balancing children with a career, and the challenges facing dual-career couples. I don't have any magical advice, as I struggle with these questions myself, but I do know it's important to communicate openly.

In a forthcoming 'white paper', my fellow award recipients and I argue that mentoring is crucial to improving technical and scientific literacy. I have recently been involved in a 'mentoring' partnership between Pennsylvania State University and Jackson State University (JSU) in Mississippi. Funded by the NSF, this 'pipeline project' aims to recruit and retain more students from ethnic minorities in the sciences, particularly in the many sub-fields of the geosciences. We're collaborating on research and developing an undergraduate programme in Earth-system science at JSU, including topics such as the long-term climate of Africa.

JSU now plans to hire two new faculty members in the geosciences. It's a start. As with one-to-one mentoring, the key has been to listen carefully to our JSU colleagues to help them achieve their goals.

Tanya Furman is an associate professor of geosciences at Pennsylvania State University.

\section{GRADUATE JOURNAL}

\section{Stumbling at the finish line}

I'm trying hard to write the last chapters of my thesis. I'm very close to the finish line, but the last bit has been the most trying. Various social outings, not to mention the epic Hawaiian surf, beckon me.

A month ago, I thought I would be done by now. It seems as though time has accelerated as the race approaches the end. Or perhaps I' $m$ just slowing down. I want to finish, and I'm not fatigued. I don't have writer's block and I'm happy with my data. But the number of distractions in my life seems to have increased exponentially.

There's a long list of friends and relatives planning to visit me this summer - when you live in Hawaii, everyone thinks you're always on holiday. I also have other research projects that suddenly need to be completed. And then there are the temptations of watching the World Cup or enjoying that amazing surf. If I could just stay on track for a short moment, maybe not chase so many waves, I'd be able to put those last few ideas down on paper. But as I overcome each distraction another appears, stronger than the previous one.

Right now, my biggest challenge is to find a way to focus as the rest of my life moves along regardless of my PhD race. My best bet may be to lock myself in my office and ignore all phone calls and e-mails - and the call of the surf. Andreas Andersson is a final-year PhD student in oceanography at the University of Hawaii. 